\title{
Tracing the Life of a Buddhist Literary Apologia: Steps in Preparation for the Study and Translation of Sokdokpa's Thunder of Definitive Meaning
}

\author{
James Duncan Gentry
}

check for updates

Citation: Gentry, James Duncan. 2021. Tracing the Life of a Buddhist Literary Apologia: Steps in Preparation for the Study and Translation of Sokdokpa's Thunder of Definitive Meaning. Religions 12: 933. https://doi.org/10.3390/rel12110933

Academic Editor: Vesna Wallace

Received: 16 September 2021

Accepted: 13 October 2021

Published: 27 October 2021

Publisher's Note: MDPI stays neutral with regard to jurisdictional claims in published maps and institutional affiliations.

Copyright: (C) 2021 by the author. Licensee MDPI, Basel, Switzerland. This article is an open access article distributed under the terms and conditions of the Creative Commons Attribution (CC BY) license (https:/ / creativecommons.org/licenses/by/ $4.0 /)$.
Department of Religious Studies, Stanford University, Stanford, CA 94305, USA; jdgentry@stanford.edu

\begin{abstract}
This article discusses Buddhist apologetics in Tibet by examining the formation, revision, and reception of the most renowned literary apologia ever written in defense of the Old School of Tibetan Buddhism: Sokdokpa Lodrö Gyeltsen's early 17th-century magnum opus the Thunder of Definitive Meaning. It reconstructs in broad strokes the history of the Thunder's reception from the early 17th century to the present and relates this to details in different versions of the Thunder and its addendum to shed light on the process by which this work was composed and edited. By considering this work's peculiar context of production and history of reception alongside passages it presents revealing how it was conceived and revised, this analysis aims to prepare the ground for its study and translation. In so doing, this discussion attempts to show how a broadly historical approach can work in tandem with a fine-grained philological approach to yield fresh insights into the production and reception of Buddhist literary works that have important ramifications for their understanding and translation.
\end{abstract}

Keywords: Buddhist literature and apologetics; Buddhist literature and authorship; Buddhist literature and intellectual history; Buddhist literature and reception; Tibetan literature; old School of Tibetan Buddhism; genre studies; philology

\section{Introduction}

It is often through argumentation and debate that assumptions which tend to otherwise remain tacit can surface. The Tibetan literary genre of "apologia" (rtsod lan, rtsod bzlog, rtsod spong, dgag lan, brgal lan) — a possible rendering of the Tibetan terms "reply" (lan) or "rebuttal" (bzlog/spong) to "objections" (rtsod, brgal) or "refutations" (dgag)—is perhaps the paradigmatic example in Tibetan literature of the productive capacity of argumentation to give voice to a wide spectrum of competing understandings on a range of issues. ${ }^{1}$ Tibetan apologia concerning the finer points of Buddhist doctrine have been amply discussed in Buddhalogical circles for some time now. But somewhat less sustained attention has been given to literary arguments in Tibet about the more fundamental question of what counts as authentic Buddhism and what the appropriate models should be for making this determination. ${ }^{2}$ Yet to be studied in sufficient depth is the voluminous apologetic literature composed specifically with the aim of defending the foundational scriptures, histories, practices, doctrines, and sacra of the Old School ( $r N y i n g ~ m a)$ of Tibetan Buddhism against charges of non-Buddhist inauthenticity-in terms of both out-and-out forgery, and the inappropriate admixture of Tibetan or Indian non-Buddhist elements. Instances of this sub-genre of apologetic literature stand out as particularly stark examples of how arguments over authenticity can bring into view a diversity of contrasting conceptions. ${ }^{3}$

This paper analyzes Sokdokpa Lodrö Gyeltsen's (Sog bzlog pa Blo gros rgyal mtshan, 1552-1624) encyclopedic masterpiece of Old School apologia the Thunder of Definitive Meaning. ${ }^{4}$ The Thunder, as I will henceforth call it, together with its addendum, probably constitutes the most renowned instance of this literary sub-genre ever authored. As an initial step toward preparing a study and translation of this seminal work, the present 
paper attempts to take stock of the history of its production and transmission to the present, with particular reference to passages that shed light on the process by which Sokdokpa composed and edited this important work. In so doing, it attempts to illustrate how textcritical and historical analysis can work in tandem to shed light on the formation, revision, and reception of Buddhist literary works in Tibet. Before we begin, however, a few general remarks are in order about the Thunder and its importance for the study of Buddhism in Tibet and the Himalayas.

\section{The Import of Thunder: A Cacophony of Perspectives}

For serious students of the history of Buddhism in Tibet, Sokdokpa's Thunder of Definitive Meaning is much more than just a rebuttal to critics of the Old School. In defending the Old School against criticisms in the early years of the 17th century, Sokdokpa was compelled to reproduce in the Thunder and its addendum several particularly rare and historically important texts. These include, inter alia, the "edicts" (bka' shog) of the leaders of the royal family of Ngari (Mnga' ris), in western Tibet, Lha Lama Yeshé Ö (Lha bla ma Ye shes 'od, 947-1019/24) and Photrang Shiwa Ö (Pho brang zhi ba 'od, 1016-1111); ${ }^{5}$ the famous "open letter" ('byams yig) of the 11th-century tantric translator Gö Lotsāwa Khukpa Lhetsé ('Gos lo tsā ba khug pa lhas brtsas); ${ }^{6}$ verses from the treatise A Clear Differentiation of the Three Codes, composed by Sakya Pạ̣ita Künga Gyeltsen (Sa skya pandita Kun dga' rgyal mtshan, 1182-1251); ${ }^{7}$ passages from the treatises Ornamental Flower of the Three Trainings, Ornamental Sunlight of the Extensive Teachings, and Ornamental Flower Establishing the *Guhyagarbha composed by Chomden Rikpé Reltri (Bcom ldan rig pa'i ral gri, 12271305), otherwise known as Darma Gyeltsen (Dar ma rgyal mtshan); ${ }^{8}$ scattered folios from the reflections of his student Gyangro Jangchub Bum (rGyang ro Byang chub 'bum, b. 13th c.) on scriptural authenticity; ${ }^{9}$ reflections on this issue in the famous History of Buddhism of Butön Rinchen Drup (Bu ston Rin chen grub, 1290-1364); ${ }^{10}$ the extensive Old School critique Distinguishing Dharma and Non-Dharma attributed to the circa 1400 figure Peldzin (Dpal 'dzin n.d.); ${ }^{11}$ and remarks about Peldzin's text from the 15th-century Sakya scholar Śākya Chokden (Shā kya mchog ldan, 1428-1507). ${ }^{12}$

Each document Sokdokpa reproduced centers on controversies in the reception of tantric Buddhist traditions in Tibet that pertain mostly to what has become known as the Old School of Tibetan Buddhism. But in furnishing this diversity of texts and responding to the issues they raise with arguments and citations drawn from numerous scriptural and historical sources, Sokdokpa's Thunder extends well beyond the boundaries of just one school. Sokdokpa has produced in the Thunder an intertextual compendium of competing perspectives-extending from the late 10th-century dawn of Buddhism's "later dissemination" (phyi dar) in Tibet to Sokdokpa's composition of the Thunder and its addendum in 1604 and 1605, respectively-regarding several of the most pressing problems faced by all Tibetan communities in their transmission of tantric Buddhist traditions to Tibet. Amply discussed in its folios are fundamental questions such as what constitutes Buddhist scriptural authenticity and how it ought to be determined; what, if any, authority should be granted to indigenously revealed rather than translated Buddhist scriptures; how, if at all, ought sexuality, violence, and the consumption of meat, alcohol, and transgressive substances figure in tantric Buddhist practice; what, if any, place should Tibetan local deities have in the practices and iconographies of Indian Buddhist mandalas; and how, if at all, should non-Buddhist Tibetan cultural practices be integrated into tantric Buddhist practice, among several others.

The participants in this debate were some of most influential scholars in the history of Tibetan Buddhism. Some of them-notably, Chomden Rikpé Reltri, Gyangro Jangchup Bum, and Butön Rinchen Drup - were instrumental in the formation of the first scriptural canons of translated Buddhist literature in Tibet, the Kangyur (Bka' 'gyur) and Tengyur (Bstan 'gyur) collections, which by the late 14th century had excluded many of the scriptures belonging to the Old School under suspicion of apocryphal authorship. ${ }^{13}$ In arguing their respective cases concerning the Old School, these scholars were able to enlist a 
staggering range of Buddhist literature-from sūtras, tantras, commentaries, treatises, narratives and other genres translated into Tibetan; to histories, biographies, catalogues, treatises and other genres of writing composed originally by Tibetans. One governing question in these richly intertextual literary arguments, though rarely stated as such, is what should be the boundaries of indigenous Tibetan contributions to Indian Buddhism in Tibet, in terms of language, imagery, sacra, contemplative practice, ritual practice, comportment, doctrinal views, and so much more, without sacrificing the "authenticity" of the Buddhist tradition? Understood thus as an ongoing conversation about how Buddhism is successfully domesticated in new socio-cultural contexts, the shape and direction of this centuries-long argument, as Sokdokpa curates it and carefully adds his own perspectives in the Thunder, has a significant bearing on the challenges all societies face in their adaptation of Buddhist traditions.

Given the historical importance of the texts reproduced in the Thunder, scholars of Tibet have for decades been mining it to glean insights into controversies over the Indian pedigree and Tibetan reception of several different Buddhist textual and practice traditions. ${ }^{14}$ And they have made many important contributions by doing so. Yet, there has been no systematic attempt to take stock of the Thunder in its own right. I would thus like to suggest that scholars of Tibetan Buddhism would be rewarded by moving beyond a partial and extractive approach to the Thunder to more wholistically consider the multiplicity of voices that this work presents. Indeed, a careful reading of the Thunder's arguments for and against the Indian Buddhist pedigree of the Old School's most cherished scriptures, practices, doctrines, and sacra can shed important light on fundamental questions about the transmission of Buddhism not only in Tibet, but wherever else it has spread. Understanding the contents of this writing, however, is complicated significantly by text-critical issues that have arisen due to the peculiar context of its production and its unusual transmission history. The present paper thus puts aside for the time being a consideration of the Thunder's multifaceted arguments to come to terms first with what can be gleaned about its composition and reception, beginning with how it first came to the attention of the global scholarly community.

\section{The Life of Thunder: Faint Echoes and Early Rumblings}

\subsection{The Reception of Thunder in the Modern Era}

The Thunder of Definitive Meaning was first introduced to the international community of Tibetan and Buddhist studies in 1969 by E. Gene Smith, in his wonderful preface to Volume 1 of the Ngagyur Nyingma Sungrab Publication Series, The Autobiographical Reminiscences of Ngag-dbang-dpal-bzang, Late Abbot of Kah-thog Monastery. ${ }^{15}$ While introducing therein the newly published Tibetan edition of Khenpo Ngaga's autobiography, Smith also offers a brief historical overview of the Old School, focusing on its most celebrated lamas and their most renowned compositions. When reaching the 16th and 17th centuries, Smith names Sokdokpa Lodrö Gyeltsen as an important figure and supplies a lengthy footnote about him. ${ }^{16}$ In this note, Smith describes the Thunder as a "brilliant refutation of the critics of the Nyingmapa Sect." He also remarks that this composition was so rare that he was only aware then of two extant copies-one in the library of the Bihar Research Society in Patna, and the other in the personal library of Düdjom Rinpoche Jikdrel Yeshé Dorjé (Bdud 'joms rin po che 'Jigs bral ye shes rdo rje, 1904-1987). Gene Smith additionally dates the composition of the Thunder to 1604, and its supplement, An Eloquent Feast of Nectar (Legs bshad bdud rtsi dga' ston), to 1605. He also states that Düdjom Rinpoche had edited both during the time leading up to the publication of this inaugural volume of the Ngagyur Nyingma Sungrab publication series.

In 1975, Sanji Dorje published in New Delhi under the auspices of Gene Smith and the US Library of Congress's Public Library 480 program (PL480) a reproduction of an incomplete dbu chen manuscript of Sokdokpa's Collected Writings, which belonged then to the personal library of Düdjom Rinpoche. ${ }^{17}$ This collection includes the entirety of the Thunder of Definitive Meaning and its addendum, grouping them together in the publisher's 
catalogue in Volume I, Cha, under the title Thunder of Definitive Meaning: An Eloquent Apologetic against Objections to the True Dharma of the Early Translation of Secret Mantra. ${ }^{18}$

A few years later, in 1982, an dbu med manuscript of the text and addendum, ostensibly reproduced from a manuscript belonging to the "Western Tibetan tradition," was published separately by Damchoe Sangpo in Dalhousie, Himachal Pradesh, India under the title Thunder of Definitive Meaning: A Reply to Queries. ${ }^{19}$ It is unclear exactly what the "Western Tibetan tradition" is intended to reference here, but what is evident is that it is nearly identical to the 1975 Collected Writings version and neither is based on the edition produced by Düdjom Rinpoche that Smith referenced in his 1969 preface.

As fortune would have it, Düdjom Rinpoche's edition has since made its appearance in the Greatly Expanded Kama (Bka' ma shin tu royas pa) collections, published in 1999 and 2009, respectively. ${ }^{20}$ Düdjom Rinpoche's edition also formed the basis for the computer input western-book format version published in 1997 and 1998 by the Sichuan Nationalities Publishing House, located in Chengdu, Sichuan, Peoples Republic of China. ${ }^{21}$ This western book version has since circulated throughout the entire Tibetan speaking world. Starting in 1999, I have personally seen this small golden-orange paperback volume available inexpensively for purchase in Tibetan language bookstores in Delhi, Dharamshala, Kathmandu, Chengdu, Kangding, and elsewhere. Owing to the widespread circulation of this book version, the Thunder can now be seen in the personal libraries of most Old School lamas and khenpos actively teaching today. Over the past 50 years, the Thunder of Definitive Meaning has thus gone from an extraordinarily rare manuscript to a commonplace reference work on nearly every Old School teacher's private bookshelf. Today, most of these versions are freely available digitally through the graces of Gene Smith's Buddhist Digital Resource Center (BDRC, formerly Tibetan Buddhist Resource Center, or TBRC).

\subsection{The Banning of Thunder}

The rarity of the text when Gene Smith first introduced it to the Tibetological world in 1969 is likely due in some measure to the unusual posthumous reception and transmission history of this and Sokdokpa's other writings. As I have related elsewhere, in 1654, fifty years after Sokdokpa completed the Thunder, and only thirty years after his passing in 1624, the reading, copying, and circulation of his writings were banned by none other than the leader of Tibet, the Fifth Dalai Lama Ngawang Losang Gyatso (Ngag dbang blo bzang rgya mtsho, 1617-1682). ${ }^{22}$ This ban was evidently part of the new Tibetan leader's efforts to stem lingering loyalty to the Tsangpa (Gtsangs pa) court, whose rule over Tibet the Dalai Lama government of the Ganden Photrang usurped in 1642 with the assistance of Mongol military intervention. Sokdokpa was a key ally of the Tsangpa court during the final decades of the 16th century and until his passing in 1624. As attested by his sobriquet "Sokdokpa" — meaning, "The Mongol Repeller"—Sokdokpa earned a reputation during his lifetime for enlisting on behalf of the Tsangpa court his guru Shikpo Lingpa's (Zhig po gling pa, 1524-1584) Treasure revelations, prophecy texts, and prophecy interpretations to stage a 32-year ritual and public-works campaign designed to fortify Tibet's borders and rid the land of encroaching Mongol armies. Tsangpa political rule had evidently been periodically threatened during this period by the strategic formation and strengthening since the 1570s and 1580s of Geluk-Mongol religious and military alliances.

Sokdokpa composed a memoir that presents in vivid detail his ritual campaign of "repelling" Mongol armies from Tibet. ${ }^{23}$ Sokdokpa narrates there that his ritual campaign, which he concluded shortly after 1614 , was a rousing success. ${ }^{24}$ However, he passed away in 1624 and was therefore no longer alive in 1642 to witness the Mongol military sacking of the Tsangpa fortress of Samdruptsé (Bsam grub rtse) and the installation of the Fifth Dalai Lama as leader of Tibet. Once the Fifth Dalai Lama had taken over as Tibet's new leader, he was left to contend with the remaining network of Tsangpa loyalists. Particularly sensitive was how to handle the lamas and their monastic institutions and communities that had been charged with staging the communal anti-Mongol and anti-Geluk rituals of Sokdokpa and his associates. Ngesang Dorjé Ling monastery in Gongra, Central Tibet, led 
by Sokdokpa's most high-profile student Gongra Shenpen Dorjé (1594-1654), had by then become the main institutional center for the study and practice of Sokdokpa's writings. Upon Shenpen Dorjé's passing, the Fifth Dalai Lama took the opportunity to purge the monastery of its previous associations by appointing a loyalist, Nyangtön Tratsangwa Lodrö Choki Dorjé (Nyang ston khra tshang ba Blo gros mchog gi rdo rje, 1595-1671), as abbot, and by imposing a new monastic charter that stipulated a different Old School ritual and study program. The ban placed on Sokdokpa's writings was part of these repressive measures.

\subsection{The Circulation and Transmission of Thunder}

Sokdokpa's writings might have slipped into obscurity forever had it not been for the intrepid responses to the political crisis on behalf of two of Sokdokpa's grand-studentsLhatsün Namkha Jikmé (Lha btsun Nam mkha' 'jigs med, 1597-1650) and Ngadak Sempa Chenpo Phüntsok Rindzin (Mnga' bdag sems dpa' chen po Phun tshogs rig 'dzin, 15921655). These two figures fled south on the eve of the collapse of the house of Tsangpa to collaborate in "reopening" the "hidden land" (sbas yul) of Sikkim. At a safe remove from the turmoil unfolding north in Tibet, they would end up settling in Sikkim and founding there a new Buddhist kingdom. Although conflicting narratives variously describe one or the other of these two figures as the principal religious specialist of Sikkim during this time, it was likely Ngadak Püntsok Rindzin who selected the state's first king, acted as royal preceptor at his coronation, and formed with him the patron-priest (mchod yon) relationship that was necessary to institute the large-scale architectural projects and ritual programs of the new kingdom. ${ }^{25}$

It may also have been the Ngadak Püntsok Rindzin who brought Sokdokpa's Collected Writings to Sikkim and promoted their continued study and practice there. ${ }^{26} \mathrm{Ngadak}$ Püntsok Rindzin was a fledging tantrika at the Tsangpa court in the early 17th century. His grandfather, Ngadak Takshamchen (Mnga' bdag Stag sham can, circa 16th c.), seems to have been a close associate of Sokdokpa and probably served alongside him in Mongol-repelling rituals. Ngadak Püntsok Rindzin inherited Sokdokpa's writings from his grandfather. The Sikkimese historian Khenpo Lha Tsering writes that Ngadak Püntsok Rindzin prized Sokdokpa so highly that a newly-copied version of his Collected Writings (bka' 'bum) in three volumes was given pride of place among the "receptacles of awakened speech" (gsung rten) commissioned for Püntsok Rindzin's funeral. ${ }^{27}$ The new volumes were copied to occupy the Great Sage Temple (Thub chen lha khang) constructed in 1656 at Trashiding as an offering to "fulfill the intention" of Püntsok Rindzin, who died earlier that year.

Guided by Gene Smith's advice, I visited Sikkim in 2009 and 2010 to consult a version of Sokdokpa's Collected Writings believed to be the remnants of the copy made on that occasion. This version of Sokdokpa's Collected Writings is currently held at the library of Namgyel Lhatsé (Rnam rgyal lha rtse) monastery in Namchi, Western Sikkim. It is far less complete than the published 1975 version, but it also includes four texts that had gone missing from this collection. ${ }^{28}$ These four missing texts, in addition to a fifth work, which does survive in the 1975 collection, served as exemplars for the Assorted Writings collection (gsung thor bu) published in Gangtok, Sikkim in 1985 under the heading Several Hitherto Undiscovered Wrings of the Rñin-ma-pa master, Sog-bzlog-pa-Blo-gro-rgyal-mtshan. ${ }^{29}$ This fivetext collection apparently owes its genesis to an effort to produce facsimile editions and publish together only the texts in the Namchi version of Sokdokpa's Collected Writings that were thought to be missing from the 1975 collection. Curiously, the fifth text included in this collection is the Thunder's addendum, An Eloquent Feast of Ambrosia, which does not fit this criterion. ${ }^{30}$ It seems that since the Thunder is one of the texts missing from the Namchi version of Sokdokpa's Collected Writings and the addendum bears its own title and colophon, the addendum gave the appearance of a stand-alone text to the compilers and was mistakenly selected for inclusion in the Assorted Writings collection as one of the "hitherto undiscovered writings." 
The descendants and incarnations of Ngadak Püntsok Rindzin and Lhatsün Namkha Jikmé, many of whom have ranked among the successive preceptors of Sikkim, have promoted the textual and ritual traditions associated with Sokdokpa and his guru Shikpo Lingpa until the present. Moreover, another important grand-disciple of Sokdokpa, Tsélé Natshok Rangdröl (1605/8-1677), whose writings also became rare and circulated primarily in Sikkim, reports in his autobiography as having received "the peerless Sokdokpa's collected works and assorted teachings" (mnyam med sog zlog pa'i bka' 'bum kha thor) from Sokdokpa's student Gongra Shenpen Dorjé. ${ }^{31}$ There is also evidence that the transmission of Sokdokpa's writings to these and other figures before the ban was put in place, and/or outside the Fifth Dalai Lama's sphere of influence, gave occasion for additional copies to be made and circulated throughout the region. Three additional versions of the Thunder of Definitive Meaning - one complete and two others missing a few folios-have since been rediscovered, thanks to the Nepalese-German Manuscript Preservation Project (NGMCP), among the personal libraries of Old School lamas active in the highlands of Nepal—specifically in Tengboche, Nathang Koti, and Thimi. ${ }^{32}$ Photographs of these versions are now housed at the National Archives of Nepal, in Ramshah Path, Kathmandu. I was unfortunately unable to access these for the present paper. Whether the versions found in Nepal stem from the Sikkimese version or from another as yet unknown recension must therefore await future research.

Ironically, it was the Fifth Dalai himself and his regent Sangyé Gyatso (Sangs rgyas rgya mtsho, 1653-1705) who helped enshrine Sokdokpa in the annals of Tibetan literary history by critically referencing his compositions in their own writings not long after the Tibetan leader sealed Sokdokpa's works from the inquisitive eyes of others. ${ }^{33}$ Soon thereafter, moreover, Sokdokpa resurfaced as an integral link in Old School lineage histories. ${ }^{34}$ In time, the Thunder also began to openly recirculate, as evinced by references and citations in the works of 18th and 19th century Tibetan scholars. ${ }^{35}$ However, judging by the observations of Gene Smith, by 1969 the Thunder's circulation had come nearly to a halt. Although the destructive turmoil brought on by the Cultural Revolution might have had a hand in the Thunder's rarity in the latter half of the 20th century, the earlier repressive measures of the Fifth Dalai Lama surely also played some role. Whatever the case, the Thunder would not reach a wider readership until Gene Smith and Düdjom Rinpoche reintroduced it in the 1970 s and 80 s.

\section{Composing Thunder: Writing, Reception, Revision}

\subsection{Context of Production}

More can be gleaned about the composition and reception of the Thunder from Sokdokpa's own writings, and especially from the Thunder itself. In Sokdokpa's autobiographical account of the Mongol army-repelling ritual campaign that occupied most of his energies between the years of 1587 and 1614, he narrates that he took something of a hiatus from his martial ritual project between the years of 1604 and 1605 out of despondence over a confluence of personal and public misfortunes that he interpreted to bode ill for the success of his endeavors. ${ }^{36}$ This intermission seems to have freed Sokdokpa up to take on more extensive writing projects than he had previously attempted. Sokdokpa records in the colophon of the Thunder that he completed its composition on the first day of the month of śävana (gro bzhin) in the Wood Dragon Year, which corresponds to July 27th, 1604. ${ }^{37}$ There he refers to himself as "the indolent one Sokdokpa." 38 About ten months later, on May 31st or June 1st of 1605, he completed his composition of an addendum to the text entitled An Eloquent Feast of Ambrosia. ${ }^{39}$ The colophon of this text's different versions variously record the author's identity in abbreviated form as either "the indolent one," or as "the one named Sokdokpa." 40 Together, the Thunder and its addendum stand out as the longest of Sokdokpa's surviving writings.

Sokdokpa does not record in the colophon where he wrote the Thunder. He does, however, relate that a political leader with the title of "myriarch leader," or Tripön (khri 
dpon), by the name of Norbu Pema Gyelpo (Nor bu padma rgyal po) requested its composition. Sokdokpa extolls him there as "He who protects the earth in accordance with the Dharma, the Tripön Norbu Pema Gyelpo, who has supreme undivided faith in the boundless teaching of the Conqueror, possesses the vision of knowledge for carefully analyzing all objects of knowledge, and in particular, possesses the virtue of confidence in the way of the Vajrayāna of secret mantra." ${ }^{\prime 11}$ The saga of this patron's successive requests to Sokdokpa for the writings that he eventually stitched together to form the Thunder will be discussed below. Unfortunately, however, I have had limited success thus far in determining precisely who this figure was and where he was active.

The Thunder's addendum thankfully provides more information. Its colophon records that Sokdokpa composed this final section at Yellow Springs monastery (Chu mig ser po'i dgon pa). ${ }^{42}$ The Namchi version alternatively describes the place of composition in greater detail as "the temple of the great [monastic] community (sde chen) at Glorious Yellow Springs, the abbatial seat (gdan sa) of the Omniscient Great Scholar, Sangyé Sangpowa, one of the five ethical emanated monks prophesied by the Glorious Master of Uḍdiyanna, the Second Buddha, Padmasambhava." ${ }^{\prime 3}$ Scarcely little is known about this abbot and his monastery, but other sources indicate that Yellow Springs was within or in close proximity to Sokdokpa's native territory of Uyuk, in the Tsang region, due north of Samdruptsé Palace in Shikatsé, on the northern side of the Yarlung Tsangpo river. For instance, Pawo Tsuklak Trengwa, in the biography of Potawa Rinchen Sel (Po to ba Rin chen gsal, 1027/1031-1105) contained in his history A Feast for Scholars, mentions Yellow Springs as being in the vicinity of Uyuk and Shang. ${ }^{44}$ Yellow Springs also appears as the place of composition in the colophon of another of Sokdokpa's writings, completed in the Water Hare year of $1603 .{ }^{45}$ Sokdokpa records in his memoir that he was active at Gö Ngön (Gos sngon) temple, in Uyuk, between the years of 1602 and 1603. Taken together, these clues suggest that he resided periodically at Yellow Springs between the years of 1603 and 1605, perhaps moving between there and Gö Ngön temple until 1604. This might imply that the Tripön Norbu Pema Gyelpo was also active in this area of Tsang.

\subsection{Structure}

Turning now to the structure of the Thunder, the catalogue (tho byang) of Sokdokpa's collected works, whose first-person voice gives the distinct appearance that it was written by Sokdokpa himself at some point later in his life, lists eight section titles. ${ }^{46}$ The Thunder as it has been received today also has eight sections, but their order and grouping are slightly inconsistent with what we find in the catalogue. The catalogue reads as follows (the numbers are my own addition):

1. Abandoning Objections to the Old School of Mantra: A Reply to the Objections of Drikung Peldzin ${ }^{47}$

2. Two Sections Offered in Reply to the Edict of Lha Lama Yeshé $\ddot{O}^{48}$

3. A Reply to the Edict of Photrang Shiwa $\ddot{O}^{49}$

4. A Reply to the Ordinance of the Great Lotsāwa Gö Lhetse ${ }^{50}$

5. A Writing Offered in Reply to Chomden Reltri ${ }^{51}$

6. A Writing Commenting Precisely on the Opinions of the Great Personage Sakya Pandita and the Great Pandita, the Omniscient One, the Great Butön ${ }^{52}$

7. An Extract from a Corpus Serving as an Excellent Support for the Old School of Mantra Given by Śäkya Chokden in Reply to Questions Posed to him by Chapa Chöjé Kelsang ${ }^{53}$

8. A Writing Presenting My Own Impartiality, with Support from Assorted Teachings of Gyangro Jangchup Bum ${ }^{54}$

The list ends with a statement suggestive of Sokdokpa's conception of how these sections ought to hang together: “ ... combined with [the final text], these are formed 
together into one textual grouping." 55 Sokdokpa goes on in the catalogue to list this "one textual grouping" with other separately titled works under the governing genre label of "apologia" (rtsod bzlog)—literally, "rebuttals to objections." 56

Nowhere in the catalogue is this "one textual grouping" inclusive of the Thunder's sections labeled with an overarching title. The Thunder as it has been handed down to us today, however, is clearly designated with a title, not only on the title page of its many versions, which were likely added later, but in the colophon of the text itself, prior to the final addendum that corresponds to section eight above. ${ }^{57}$ There, Sokdokpa calls his treatise the Thunder of Definitive Meaning: An Eloquent Rebuttal to Objections to the True Dharma of the Early Translation School of Secret Mantra. ${ }^{58}$ In the colophon of the addendum, moreover, Sokdokpa titles the addendum An Eloquent Feast of Nectar to be Communicated for Followers of the Dharma, or alternatively, in the Namchi version, An Eloquent Feast of Ambrosia to be Communicated for Clarifying My Own Doubts. ${ }^{59}$ The issue of variation between different versions of the addendum will be addressed below.

The titles of the Thunder and its addendum are not the only major variations. The work of the Thunder itself reflects a slightly different structure and includes section titles that are sometimes at odds with what Sokdokpa records in his catalogue. Although the reply to Peldzin's critique begins the body of the text, thus reflecting the catalogue, sections two, three, and four in the catalogue-replies to the critiques of Lha Lama Yeshé Ö, Potrang Shiwa Ö, and Gö Lotsāwa Khukpa Lhetsé, respectively - are grouped together in the body of the text and do not form distinct sections. These are also followed by another short section, not listed in the catalogue at all, called A Presentation of the General Teaching - this constitutes section three in the body of the text. Sections four, five, and six in the body of the text are Sokdokpa's replies to Butön, Sakya Pandita, and Chomden Rigrel, respectively. This contrasts markedly with the sequence and grouping of the catalogue, in which the reply to Chomden Reltri is section five, and the replies to Butön and Sakya Pandita are grouped together as section six, but with their order reversed. Here is a table comparing the eight sections as they appear in the catalogue and in the text itself, respectively.

\begin{tabular}{ll}
\multicolumn{2}{l}{ Sections in Catalogue } \\
1 & Peldzin \\
2 & Lha Lama Yeshé Ö \\
3 & Potrang Shiwa Ö \\
4 & Gö Lotsāwa Khukpa Lhetsé \\
5 & Chomden Reltri \\
6 & Sakya Paṇịita, Butön \\
7 & Sākya Chokden \\
8 & Gyangro Jangchup Bum
\end{tabular}

\subsection{Process of Composition and Revision}

The inconsistencies between the order of the Thunder's sections in Sokdokpa's catalogue and in the body of the composition itself likely stem in part from the piecemeal fashion in which Sokdokpa composed it. Sokdokpa is explicit in the Thunder's section and concluding colophons that he did not originally conceive of the text as a coherent whole, but wrote it in sections over the years of 1604 and 1605, sporadically, in response to a series of requests from Norbu Pema Gyelpo. Only later, Sokdokpa clearly implies, when he completed the addendum in 1605, did he combine the different parts to form the larger work of the Thunder.

At the end of section one, for instance, Sokdokpa relates that he wrote his reply to Peldzin's critique, far and away the longest section of the text, only in response to the reception of another writing he had composed earlier. As Sokdokpa describes it, he started writing what would become the Thunder with the more modest goal of only composing a reply to Old School detractors of the 15th-century Sakya scholar Śākya Chokden, whose 
citation of Peldzin's critique of the Old School in his commentary on Sakya Pandita's A Clear Differentiation of the Three Codes appears to have set off a storm of resentment among Old School adherents against the presumably anti-Old School legacy of this highly esteemed scholar. Sokdokpa adopts the literary convention of addressing Peldzin directly to describe the sequence of events as follows:

A copy of this complete treatise of yours (i.e., Peldzin's treatise) is rare.

Yet, in his Eloquent Golden Needle (Legs bshad gser gyi thur ma),

Panchen Śākya Chokden cited it in paraphrase form with an underlying intention in mind.

That supreme scholar's intention

has not been comprehended by anyone whosoever,

so most have held it to have been straightforward [in intention].

Some Old School adherents,

lacking the intellect for cutting through superimpositions concerning this point,

have thus denigrated the supreme scholar.

In order to turn them away from [such an] evil deed,

I previously composed a response to that [point].

Later, having given me a copy of Peldzin's text with his command, the Dharma King, Lord of men,

bestowed the burden of his authority, stating:

'Previously there has never before been

a suitable rebuttal to this [treatise by Peldzin],

so it appears that most

have been deceived by it.

Thus, deliver an extremely suitable rebuttal. ${ }^{68}$

Particularly noteworthy here is Sokdokpa's mention that the Śākya Chokden-related section-section seven-was the first section of the Thunder he composed. Only after he finished section seven did he receive the commission to write the Peldzin rebuttal that forms section one. Another important detail here is Sokdokpa's mention of the rarity of Peldzin's text during his time and his citation of his patron to the effect that no suitable rebuttal had yet been composed.

Sokdokpa provides more detail about the process of his composition of the Thunder in the opening and closing passages of its addendum. Significantly complicating a clear understanding of these passages is that the Namchi version $(\mathrm{N})$, a reproduction of which is preserved in the Assorted Writings published in 1985, is markedly different from the version in the published Collected Writings (D), the dbu med manuscript published in Gangtok (DA), and the Düdjom edition in the Greatly Expanded Kama collection of 1999 (K). These textual variations provide additional important clues into the Thunder's composition and revision.

Major differences between these versions first appear in the addendum's opening preamble:

Versions D, DA, and $\mathrm{K}$ read as follows:

Concerning the series of replies to criticisms expressed above by us [in Thunder], there are genuine replies, applicable replies, and scriptural citations from sūtras and tantras are copiously enlisted. Nonetheless, not only have Old School adherents not asked me about what is in it; even New School adherents trained in sütra and mantra have remained silent about it-I have thus been overcome with sadness. While it is indeed true that someone like me is not someone with whom scholars would ask questions and discuss the Dharma. Nonetheless, to distin- 
guish between the interpretable and the definitive, to clarify my own doubts, and to provide an addendum to this treatise, I will offer an explanation based on the sütras and tantras I subsequently saw and understood, as based specifically on a few scattered folios I found from the teachings of the spiritual mentor known as Narthangpa Gyangro Jangchub Bum. ${ }^{69}$

Version $\mathrm{N}$, translated below, provides more detail.

We have put forth herein (i.e., in Thunder) citations from sūtras and tantras that are intentional and literal in reply to the individual open letters of Lha Lama Yeshé Ö, Potrang Shiwa Ö, and the great translator Gös Lhetsé; and in reply to the versified treatise of Drikung Peldzin's refutation of the Old School, and to the open letter delivered by Peldzin to Karmapa Könshön. Not only have Old School adherents not asked me or debated with me about what is in it; even New School adherents trained in sütra and mantra have remained silent about it - this has been a point of sadness. While it is indeed by all means true that someone like me is not someone with whom learned scholars would discuss the Dharma. Nonetheless, if the interpretable and the definitive are not distinguished, there is a grave risk that future people with little learning will be confused and cleave to the wrong path. Moreover, since there have appeared so many instances of past New School scholars proclaiming to be non-Dharma things that resolutely are Dharma, if those that have subsequently been resolved to be authentic can be discussed in one place, it would be a service to the teaching. With the understanding also that it will clear up my own doubt, I put forth the following based on reading sources that have contributed to my understanding, from among the Buddha Word and treatises I have seen in keeping with the fortune of my own merit, and specifically based on reading a stray folio of the teachings of the great spiritual mentor of all, the one who appeared at Glorious Narthang called Gyangro Jangchub Bum. ${ }^{70}$

Much can be gleaned from these passages and their differences about the composition and reception of the Thunder and its addendum. We learn foremost, from the expanded passage of version $\mathrm{N}$, that Sokdokpa's project was not just for the here and now. It was for posterity, to provide for future generations a model for discerning the difference between scriptures of definitive and interpretable meaning and to pass on a historical record of all the controversial scriptures which had been demonstrated to be authentic since they were first called into question.

We can see in both versions that Sokdokpa was also concerned with the reception of the Thunder and its addendum. He confesses to being sad by the fact that the Thunder had been received by his colleagues with silent indifference, despite his best efforts to make it a compelling composition, replete with citations. This might help explain version N's enlarged research agenda and materials. We can see in N's more detailed description that Sokdokpa lists his replies to not only the "open letters" of Lha Lama Yeshé Ö, Potrang Shiwa Ö, Gös Khukpa Lhetsé; and the "versified treatise" of Drikung Peldzin's refutation of the Old School; he also mentions having composed a rebuttal to the "open letter delivered by Peldzin to Karmapa Könshön." The name Karmapa Könshön also appears in the addendum's closing verses, in all versions of the text, as follows:

I have seen a suitable reply (lan thebs po[D, DA 'debs po])

composed by the Karmapa known as Könshön

to the objections delivered to him by Peldzin. ${ }^{71}$

However, Karmapa Könshön does not appear anywhere else in the Thunder, and neither is there any other explicit mention of Peldzin's letter to him, or any other "suitable rebuttal" beyond Sokdokpa's own. Peldzin's associate Karmapa Könshön refers in all likelihood to Karma Könchok Shönu (Karma dKon mchog gzhon nu), the late 14th-century student of the Karmapa IV Rölpé Dorjé and close associate of the Sakya lama Rendawa 
Shönu Lodrö (Red mda' ba gZhon nu blo gros, 1349-1412) and other major scholars of the period. $^{72}$

In the interest of space, I will have to leave for another discussion the questions of what precisely Karma Könshön's relationship was with Peldzin, and where, if anywhere, in the Thunder we might find traces of Sokdokpa's rebuttal to Peldzin's epistle. ${ }^{73}$ For the purposes of the present paper, I would like to simply point out that Sokdokpa refers to Karma Könshön's earlier "suitable rebuttal" to Peldzin in the addendum, whereas in the colophon of Section 1 of the Thunder, composed by Sokdokpa about ten months earlier in reply to Peldzin's verse critique, there is no mention of this rebuttal whatsoever, and his patron is reported by Sokdokpa as having said that no such thing exists. This observation, coupled with version N's reference to Sokdokpa's continued research on the topic through his reading of scriptural sources that he had not been able to consult before composing the addendum, and the intentional revisions that can be witnessed in version $\mathrm{N}$ of the addendum itself, all reflect the nature of a work that was still very much in progress - even after the colophon's date of composition, which remains consistent in all versions. This stands to reason given Sokdokpa's explicit concern with the reception of the Thunder, the possible future readership of the Thunder's addendum, and his projection of the addendum as a testament that could once and for all record "in one place" all the determinations about scriptural authenticity that had been advanced in the centuries leading up to his time.

The impression that the addendum as we have it was still a work in progress, even after the date given in its colophon, is enhanced further when comparing the closing prose passage and verses that make up the colophon. Telling discrepancies are first noticeable in the prose section that immediately precedes the concluding verses.

Versions D, DA, and $\mathrm{K}$ read as follows:

Now if someone with meager intelligence like me can find such, then if many scholars with accumulation and purification were to expand their reading, they would gain the certainty of definitively establishing to be authentic Dharma everything that has been heard of previously here in Tibet to be inauthentic Dharma. $^{74}$

Version $\mathrm{N}$ reads instead:

Now if someone with meager intelligence like me can with effort find such, then if those with accumulation and purification who possess the vision of wisdom were to expand their reading and read the life stories of the individual translators of the past and all their treatises, they would gain the confidence that everything heard of previously here in Tibet as inauthentic Dharma is in fact authentic Dharma. Even if they are not able to read that much, such would be clear from reading the General Presentation of the Tantra Classes, the Refutation of False Mantra, the commentaries on the individual tantras, and the sädhana mandalas and so forth, composed by the great translator Rinchen Sangpo. ${ }^{75}$

The extended colophon of version $\mathrm{N}$ above offers another window into the ongoing reading and research that went into Sokdokpa's composition and revision of the Thunder and its addendum. Whereas versions D, DA, and K simply call upon scholars concerned with the issue of authenticity to expand their reading, version $\mathrm{N}$ specifies which bodies of text, genres, authors, and titles ought to be consulted. These include, most notably, the works of the great translator Rinchen Sangpo (Lo chen Rin chen bzang po, 958-1055), such as his famous General Presentation of the Tantra Classes (Rgyud sde spyi'i rnam gzhag) and Refutation of False Mantra (Sngags log sun 'byin). ${ }^{76}$ Moreover, these additional sentences in version $\mathrm{N}$ are so integrally worked into the passage that the inadvertent assimilation of intervening interlinear notes seems an unlikely reason for the expansions we witness in version $\mathrm{N}$. Version $\mathrm{N}$ seems rather to be a deliberate and careful revision of what we find in versions $\mathrm{D}, \mathrm{DA}$, and $\mathrm{K}$.

In the closing verses that follow this passage in the addendum, Sokdokpa walks readers through his process of composing the Thunder in the context of narrating a brief 
history of Buddhist apologetics in India and Tibet, and a summary of his own career as an apologist up until the year of 1605, when he completed the addendum. Here too, there are significant variations primarily between versions $\mathrm{N}$, on the one hand, and versions $\mathrm{D}$, $\mathrm{DA}$, and $\mathrm{K}$, on the other, which not only shed more light on the rationale and structure of the Thunder, but also provide another view into the process by which it was edited and revised. The nature of the variations here-phrases and entire lines systematically reworded and/or reordered, instances of two lines combined into one, the addition or omission of lines, and the addition or omission of a lengthy interlinear note-similarly give the distinct impression that the differences cannot be accounted for by accidental scribal errors or deliberate scribal hyper-corrections. Version $\mathrm{N}$ of the addendum appears rather to be a revision of whatever formed the basis of versions D, DA, and $\mathrm{K}$.

Below is an edition and translation of most of these verses, done primarily for the purpose of simply highlighting the differences between version $\mathrm{N}$ and versions $\mathrm{D}, \mathrm{DA}$, and $\mathrm{K}$, and not, at this stage, to produce the most "correct" readings, per se. It excludes an interlinear note that is missing partially from version $\mathrm{K}$ and entirely from version $\mathrm{N}$, and the final dedicatory verses. Variations are provided in brackets, with the major differences of version $\mathrm{N}$ provided additionally in bold typeface. Variations are recorded negatively; that is, the variations recorded in brackets are only those that differ from the main text transcribed-version D from the 1975 Collected Writings, with minor corrections occasionally introduced. I have attempted to render the substantive variations of version $\mathrm{N}$ in English translation, also providing these in brackets, but sometimes the changes do not lead to substantively different translation choices and can be left as is, even though the Tibetan might have been reworked considerably. In such cases, a discrepancy will be noticed between inconsistencies in the Tibetan and consistencies in the corresponding English translation.

sngon tshe rgya gar 'phags yul du/

/nyan thos sde pa du[N phal] ma[N mo] yis[N ches]/

/theg chen rgyal sras spyod pa'i gzhung/

/rdzogs sangs rgyas kyi bka' min zhes/

Previously, in India, the land of the noble ones, many[N most] śrāvakas alleged:

"The Mahāyāna texts with the conduct of bodhisattvas are not the Word of the perfect Buddha."

/bkag[DA, N dkag] pa byams mgon klu sgrub dang/ /thogs[D thog] med sku mched zhi ba'i[N ba] lhas /

/theg chen sangs rgyas bka' ru sgrubs[D sgrub]/

Rejected, Maitreyanātha, Nāgārjuna,

Asanga and his brother [Vasubandhu], and Āryadeva proved Mahāyāna to be the Word of the Buddha.

/sems tsam dang[N pa] ni[N dang] dbu ma dang/

/rgyud sde bzhi la zab khyad dang/

/mtho dman lam gyi nye ring dang/ [N mi la nye ring mtho dman byung/]

/bshad pa'i tshul dang grub pa'i mtha'[N grub mtha'i sgo]/

/mi 'dra tha dad du ma yod/

/ kun kyang sangs rgyas bstan par gcig/ 
Between Cittamātra and Madhyamaka, and among the four classes of tantra, there are many different profound features, relative distances according to higher and lower paths,

[N relative distance and hierarchy according to the person] styles of explanation, and tenet systems[N gateways of tenet systems], but all of them are identical as the Buddha's teaching.

/bod 'dir bka' phyag dwags[D, DA, K, N dags] shangs gnyis/

/sa skya pa dang zhi rdzogs gcod/

/rang tsho thub pa'i chos lugs brgyad/

/ kun la rtsod[DA, K, N brtsod] pa ma byung med/

Here in Tibet, there are the two Kagyü Mahāmudrā traditions of Dak and Shang, the Sakyapa, Pacifying, the [Great] Perfection, Severance, [etc.]eight Dharma traditions that can maintain their own integrity; none of them have been free of controversy.

/sngon tshe 'gos rngog rdog[D rdogs] gsum dus/ /pha rgyud ma rgyud chags sdang dar/

/chos ma yin zhes so sos dmad[K smad, $\mathrm{N}$ dmod]/

[N adds two lines:

/bka' gdams pa la dam pas skyon/

/bka' gdams pa rnams zhi rdzogs dmod/]

/de bzhin gcod la'ang nan ltar sdang/

Previously, in the time of the triad of Gö, Ngok, and Dok, the mother tantras and father tantras spread with passion and anger, and people disparaged one another, alleging,

"Yours is not the Dharma."

Likewise, there has been vehement rage against Severance too.

[N adds two lines:

Dampa insulted the Kadampa and the Kadampa disparaged Severance and the Great Perfection.]

/'jam dbyangs sa skya paṇ̣i tas[D, DA, N ta]/

/dwags[D, DA dags] po[N po'i] bka' brgyud[D, DA rgyud] gtogs pa'i chos/ /chos ma yin par bzhed pa yang/ [N/zhe nas chos ma yin par bzhed/ /de yi gsung rab bltas pas shes/ [N missing this line]

Mañjuśrī Sakya Pạ̣dita [N vehemently] maintained that the Dharma teachings among the Dakpo Kagyü are not the Dharmathis can be known by reading his writings. [N missing this line] / kha cig gsung ngag[K dag] lam ’bras kyang/ /snyan snyan bsdus pa'i tshig zin yin/ 
/rgyud sde'i dgongs pa min par smra/

Some claim that the oral teaching of Path and Fruit too is notes compiled from scattered aural teachings and not the intention of the tantra classes.

/n̄̄[DA ni] gu nā ro'i chos drug yang/

[N missing this line] /'chal zhing[K cing] bslad[DA slad] ces ding[DA deng] sang[D song] gi/ [N missing this line]

/kha 'dzin sor sos[D, DA sor] smod[D, DA dmod] res byed/ [N missing this line]

These days, rigid sectarianists insult one another, alleging that even the Six Dharmas of Nīgu and Nāro are

"misguided and corrupt."77

/mdor na bod du dar ba'i chos/

/rtsod[DA, K brtsod] pa med pa gcig kyang med/

/byang chub lam du 'thad[DA, K, N thams cad] mthun na[DA, K, N missing na] $/{ }^{78}$

/skyon dang dri ma ga la[DA gang yang] yod[DA med]/ [N/des na skyon kyi go skabs med/]

In sum, there is not a single Dharma teaching that spread in Tibet that has been without controversy.

If they agree in being suitable as paths to awakening

[N, DA, K They all accord as paths to awakening.] where could there be faults and stains? [ $\mathrm{N}$ so there is no chance that they are

faulty.]

/'on te[N kyang] tshig kyang[N rigs] ma dag la[N dang]/

/don gyi go ba phyin ci $\log [\mathbf{N} \log$ pa dang]/

/lag len spyod pa[N go rim] log pa na/

/gang de log pa'i chos su nges[N 'gyur]/

Nonetheless, if their words have been corrupted, and hence, understanding of their sense goes astray, and engagement in[ $\mathbf{N}$ sequence of] their practice is wrong, they are sure to be[N will be] false Dharma.

/skyon de dag dang bral ba na/

[N/de dag phyin ci ma log na/]

/kun kyang sangs rgyas bstan pa yin/

/rtsod[DA, N brtsod] pa tsam la nges pa med/

If free of those faults

[N If they are not mistaken]

then they are all the Buddha's teaching.

There is nothing certain about just being disputed. 
/dpal ldan dus kyi 'khor lo che/ [N/thub dbang bstan pa'i snying po mchog/] /thub pa'i bstan pa'i snying po yang/ [N/dpal ldan dus kyi 'khor lo yang/] /rgya gar pan chen du ma yis/ /chos ma yin par nan gyis byas/ /dus zhabs nā ro sha ba ris/ /sangs rgyas bstan pa'i snying por bsgrubs[D sgrub; DA, N sgrubs]/

The supreme essence of the Sage's teaching, the Glorious Kālacakra, has also insistently been construed as non-Dharma by many Indian scholars.

Kālacakrapāda Nāro and Śabari proved it to be the essence of the Buddha's teaching.

/bod du'ang[N 'dir] bcom ldan ral gri dang/ /mkhas pa'i dbang po red mda' bas[D, DA, N pas]/

/gtan tshigs mang pos chos 'di bkag[N dkag]/

In Tibet too, Chomden Reltri and the lord of scholars Rendawa enlisted many reasons to reject this Dharma teaching.

/de la rgyang ro byang 'bum dang/ /shar pa ye shes rgyal mtshan sogs/ /mang pos dus 'khor chos su bsgrubs[D sgrub; DA, N sgrubs]/ /spyir na rgya bal[D gar] bod yul du/ /'di 'dzin[N yi] mkhas grub[N grub thob] grangs[DA, N bgrangs] las 'das/

Many, such as Gyangro Jangchup Bum and Sharpa Yeshé Gyeltsen, among others, proved the Kälacakra to be the Dharma. In general, in the lands of India, Nepal, and Tibet, the scholars and siddhas upholding this have been innumerable.

[ $\mathrm{N}$ the siddhas associated with it have been innumerable.] /theg mchog gsang sngags rnying ma la/

[N adds:/sangs rgyas bstan pa ma yin zhes/]

/bod 'dir rtsod[DA, $\mathrm{N}$ brtsod] pa snga phyir mang[N dar]/ /rtsod[DA, N brtsod] lan[DA len] 'brel med mang po'ang[N po] yod[N snang]/ /mkhas pa mgu ba'i legs bshad med/

Here in Tibet, there have been many[ $\mathbf{N}$ there have spread] earlier and later objections to the supreme vehicle of the Old School of secret mantra,

[N adds: alleging, "It is not the Buddha's teaching."] and there has also been[ $\mathbf{N}$ appeared] many irrelevant replies to those objections; they have lacked the eloquence to please scholars. 
/mkhas pa'i mkhas pa rong[D zong] zom pa[DA, K, $\mathrm{N}$ dang]/

/ rog[D rong] gi bandhe shes rab 'od[N 'od kyis]/

/mkhas mchog thang ston lo tsā ba/

[N missing this line]

/de ltar gsum gyis[D, DA gyi] lung rigs[D, DA rig] dang/ [N combines this and the following line into/lung rigs[emend. rig] 'brel ba'i gtan tshigs kyis/] /gtan tshigs bzang po du ma yis/

/gsang sngags zab mo bka' ru bsgrubs[D sgrub; DA, N sgrubs]/

/mi phyed[N ched] snying nas dad pa thob/

The scholar among scholars Rongzompa, the bandhe of Rok Sherap Ö,

and the supreme scholar Thangtön lotsāwa-the three- [N missing this line] proved through scripture and reasoning, [N combines these two lines into one: proved through arguments combining scripture and reasoning] and through many good arguments, that this profound secret mantra is the Word [of the Buddha]; undivided heartfelt devotion was gained.

/ sangs rgyas dngos su'du shes skyes/

/kun mkhyen dri med 'od zer gyis/

/rnying ma bka' sgrub yod par grags/

It is rumored that there is a proof of the Old School as Buddha Word by the Omniscient One Drimé Öser, who is viewed as a buddha in person.

/bdag 'dra'i[K 'di'i] skal[N bskal] bas ma mthong kyang[K yang]/ /dkon[K dgon] gzhon[D, DA bzhon] zhes pa'i karma pa/ /de la dpal 'dzin gyis[D gyi] bskur[D bskur] ba'i / /rtsod[DA, N brtsod] lan[DA len] thebs[DA 'thebs] par mdzad pa mthong/

Those with fortune like mine have not seen it, but I have seen a sufficient reply composed by the Karmapa known as Könshön to the objections delivered to him by Peldzin.

/dus phyis rgyal ba karma pa/

/mi bskyod rdo rje'i 'byams yig la/

/rtsod[DA, N brtsod] lan[N len] rim pa gsum tsam mthong/

/kun kyang mu cor kho na las/

/don ldan tshig gcig mi snang bas/

/skyo ba skyes nas mchi[DA, N'chi] ma shor/

I saw only three series of replies to the objections to the later open letter of the Gyelwa Karmapa Mikyö Dorje.

But they are all nothing more than mere commotion- 
not a single meaningful word appears among them, which saddened me to the point of crying.

/rtsom[DA, N brtsom] pa'i mtshan nyid mi ldan yang[K, N kyang]/

/rang lo nyi shu rtsa lnga'i tshe/

/dris lan lung rigs[D, DA, K, N rig] 'brug sgra byas/

Although I lack the qualifications for composition, when I was twenty-five years old,

I composed the Thunder of Scripture of Reasoning: A Reply to Queries. ${ }^{79}$

/de rjes bka'[DA, K, N 'ga'] yis[DA yi] bskul ba dang/

/paṇ chen shākya mchog ldan la/

/ rang phyogs 'ga' zhig[D yis] sdang ba yi[D yis]/

/sdig las bzlog[D ldog] pa de phyir du/ [N/sdig las bzlog phyir gser thur du/] /legs bshad gser gyi thur ma ru/ [N missing this line]

/drangs[D drang] pa'i[D ba'i] dpal 'dzin rtsod[DA, N brtsod] pa'i lan/

/'ol[D 'o; K ngol] le[K la] ba zhig[D, DA gcig; N cig] bris nas yod/

Thereafter, prompted by a command

and to turn some in our group away from the infraction

of hostility toward Pạ̣chen Śākya Chokden,

there is a rough reply I wrote

for the [fact that] the objections of Peldzin

are cited in [Śākya Chokden's] Eloquent Golden Needle.

/slad du khri dpon mi'i[DA yi] dbang po/

/chos rgyal nor bu padma'i bkas/

/lha rgyal bla ma ye shes 'od/

/ zhi ba 'od dang 'gos lo tsā'i/

/'byams yig gsum dang dpal 'dzin gyi[DA, N gyis]/

/rtsod[DA, K, N brtsod] pa rgyas pa'i lan kyang byas /

Later, due to the command of the Kripön, the leader of men,

Chögyel Norbu Pema,

I produced replies to the three open letters

of Lha Lama Yeshé Ö,

Shiwa Ö, and Gö Lotsāwa,

along with a reply to the detailed criticisms of Peldzin.

/de dag kun gyi kha skong[N skongs] dang/

/bdag cag lta bu'i rigs[DA rig] can gyis[D, K gyi]/ [N moves this line below the next.]

/slad nas 'byon pa'i rnying ma bas[ $\mathrm{N}$ ba]/

[N moves here the line/bdag cag lta bu'i rigs can gyis/]

/drang[NA drangs] nges rnam dbye ma phyed dogs/ 
/dge ba'i bshes gnyen rgyang ro ba'i/

/bstan bcos rnam dag[D, K gzhag] la brten[DA, $\mathrm{N}$ rten] nas/ [N/bstan bcos tshad ma gzhir byas te/]

/yi ge'i lam du gsal bar bkod/

As a supplement to all of these,

and out of concern that future Old School adherents

of a type like us

will not be able to differentiate between the interpretable and the definitive,

[N adds: [And] to dispell my own doubt]

I have clearly put forth this [addendum] in writing,

based on an authentic treatise [ $\mathrm{N}$ taking as my basis the authoritative treatise]

of the spiritual friend Gyangrowa. ${ }^{80}$

\section{Concluding Remarks}

This consideration of the composition and reception of Sokdokpa's Thunder of Definitive Meaning has yielded several observations. To retrace and thread these together some, we have observed that Sokdokpa's composition of the Thunder, as he himself describes it in sectional and final colophons, took place in stages over the course of 1604 and 1605, in acquiescence to the repeated entreaties of the political leader Norbu Pema Gyelpo. It started with a relatively short piece in reply to Old School misconceptions regarding Sākya Chokden's controversial citation of Peldzin's critique of the Old School, which now forms section seven of the Thunder. Norbu Pema Gyelpo then gifted Sokdokpa a manuscript of Peldzin's verse polemic, which had apparently already become quite rare by Sokdokpa's time, requesting that he compose a "suitable reply" to it, and, "along the way" (zhar la), compose as segues replies to the related writings of Lha Lama Yeshé Ö, Shiwa Ö, and Khukpa Lhétsé. These now constitute sections one and two, respectively. Section three, as mentioned above, has no corresponding entry in the catalogue. This, along with sections four, five, and six-pertaining to Butön, Sakya Paṇita, and Rikpé Reltri, respectively-appear to have been the final sections composed, as they either newly appear, as in section three, or were reordered and regrouped, as in sections four, five, and six, after Sokdokpa's composition of his catalogue. This was all prior to Sokdokpa's composition of the addendum over the course of the following year based on research he had done in the interim, which yielded stray folios (or a single "folio," as in version $\mathrm{N}$ ) from the writings of Gyangro Jangchub Bum, among other relevant references and citations.

That the Thunder was completed in late July of a Dragon year might be significant in helping to explain some of the inconsistencies in the Thunder and the authorship of an addendum. Given the Tibetan astrological penchant for starting and completing projects during particularly auspicious times, Sokdokpa could have easily felt compelled to complete the Thunder-literally, in Tibetan, the dragon's roar ('brug sgra)—during late July of the Dragon year, when the monsoon season would be in full swing and thunder could be readily heard. He had probably already decided earlier to pattern the title of this work after his first apologetic writing, the Thunder of Scripture and Reasoning, composed 28 years prior. It is not inconceivable that with such considerations in mind Sokdokpa felt rushed to finish the Thunder of Definitive Meaning that summer, so decided to put off its final touches for later and develop in an addendum the stray bits of research that he was unable to properly organize in time. It is in any case clear from the addendum that Sokdopa kept reading, researching, and revising over the course of the following ten months or so, and probably thereafter as well.

The tremendous care he put into not only composing the Thunder, but also finishing it at such an auspicious time, might have also contributed to his anxiety over its reception. In the Thunder's addendum, Sokdokpa voices his frustration about the lack of receptivity to the 
Thunder among his peers, whom, he claims, received this work with complete indifference. He also projects the ideal readership for his composition into the future, suggesting that the real value of the Thunder and its addendum might only be recognized by subsequent generations. In this, Sokdokpa was partially correct. The Thunder and his other writings would attract considerable attention in the decades after his passing in 1624. Yet it was not with accolades that his writings were then received, but with censure. The circulation and copying of the Thunder and its addendum, along with Sokdokpa's other compositions, were banned in 1654 throughout the jurisdiction of the Ganden Potrang government under the express order of the Fifth Dalai Lama-thus meeting a far more deleterious fate than an indifferent and lackluster readership. This might help explain to some degree the extraordinary rarity of the Thunder and its addendum prior to its introduction to the English-speaking world by E. Gene Smith in 1969 and its initial publication under his auspices in 1975. Like all banned books, however, the Fifth Dalai Lama's act of censorship would also help ensure that the fame of Sokdokpa's Thunder would roar throughout the Tibetan Buddhist world up until the present.

In the years leading up to the ban, Sokdokpa's Collected Works had already circulated to Sikkim, where an incomplete copy presently remains housed at Namchi monastery. Although the Thunder is no longer part of this Namchi collection, the addendum is. This version of the addendum, moreover, along with the other writings in this collection, could very well be from the copy of Sokdokpa's Collected Writings made in 1656, in Tashiding, Sikkim, based directly on the exemplar brought to Sikkim from Tsang a few years prior. The Namchi version of the addendum contains several expanded and reworked passages, as compared to the other published versions of D, DA, and $\mathrm{K}$. The brief presentation above of the addendum's opening and closing sections illustrates that the variations observable in version $\mathrm{N}$ were the result of deliberate editorial work. Moreover, that these revisions are cast in the first-person authorial voice of Sokdokpa himself suggests that they might very well reflect Sokdokpa's own revisions. Although this suggestion is conjectural at this stage of research, if version $\mathrm{N}$ does indeed represent Sokdokpa's own revisions, we may well have in the different witnesses of the Thunder's addendum a rare glimpse into the research, writing, and editorial practices of this 16th- to 17th-century Tibetan scholar.

However, if we heed the first-person plural that appears in the addendum's opening preamble and presume that the revisions in version $\mathrm{N}$ were not done by Sokdokpa, or not by him alone, but by another, or several others, either during or shortly after Sokdokpa's lifetime, then the editorial reworking of the addendum could provide evidence for a collective sense of authorship. Old School inheritors of this text might have felt permitted by the apologetic imperative, which concerns all Old School adherents, to take over authorship of the text and transmit a revised version or versions. We can witness in Düdjom Rinpoche's revision that his editorial approach was mostly limited to correcting for posterity the spelling mistakes and grammatical problems that had accidentally crept into the text over the course of centuries of careless copying. He does so, moreover, not anonymously, but by adding to his edition (version K) an editorial colophon. ${ }^{81}$ But Düdjom's light-handed approach is entirely at odds with the editorial practice witnessed in the addendum. And such transparency in acknowledging one's own editorial contributions has certainly not always been a high priority among Tibetan scholars and scribes.

But regardless of whether these variations reflect Sokdokpa's own revisions, a collective sense of Old School stewardship over Sokdokpa's project, or a combination of both, examination of these features of the text in their historical context throws into sharp relief the importance of combining historical and text-critical analysis as a foundation for the study and translation of Tibetan literary works. The findings of this effort amply suggest that it is by first attempting to trace the history of a literary work's composition and reception-its storied "life," from conception to the present, with all its manifold transformations and associations - that the ground can be best prepared for a rich understanding of its contents. In this vein, the present remarks represent an initial gesture toward preparing the ground for the study and translation of Sokdokpa's masterpiece of Old School apologia, 
Thunder of Definitive Meaning, whose peculiar vicissitudes have made its accessibility to wider audiences long overdue.

Funding: This research received no external funding.

Institutional Review Board Statement: Not applicable.

Informed Consent Statement: Not applicable.

Data Availability Statement: Not applicable.

Conflicts of Interest: The author declares no conflict of interest.

\section{Notes}

1 (Lopez 1996, fn2) prefers "polemics" for this set of terms. Citing Schleiermacher's distinction between polemics and apologia, he argues that polemics refers to doctrinal disputes within a community, whereas apology concerns itself with more general faith claims directed to redress criticisms coming from outside a community. (Raudsepp 2009, p. 292fn2) follows suit. However, "apologia" has the advantage of including both objections and rebuttals, whereas "polemics" only concerns objections. Moreover, as (Onians 2003, pp. 63-65) argues, several important early Christian apologias were written for readerships that included fellow Christians within a community, not just pagans and Jews outside it; and, more pointedly, the term apologia need not be confined to its historical Judeo-Christian usages. A final apology for the rendering of these Tibetan genre labels as "apologia" is, as we will see below, the presence of an important sub-category of this genre concerned not with arcane doctrinal points, but with the more fundamental issue of what constitutes authentic Buddhism. For a brief review of these and related genre labels, see (Raudsepp 2009, p. 281).

2 (Lopez 1996), for instance, entirely disregards writings in this genre that are not devoted exclusively to doctrinal issues. For discussion of such arguments over authenticity, see (Mayer 1997; Kapstein 2000, pp. 121-37; Wangchuk 2002; Schaeffer and van der Kuijp 2009; van der Kuijp 2018a, 2018b; Almogi 2019, 2020).

3 (Dudjom 1991, pp. 887-942) offers in English translation a relatively recent and particularly rich example of this body of literature, based on several earlier sources. The Tibetan is in (Bdud 'joms 'Jigs bral ye shes rdo rje 1967, pp. 695-776). For a brief general introduction to this body of literature, see (Raudsepp 2009, pp. 281-85). For a discussion of this literature as it pertains to the authenticity of Treasure revelation in particular, see (Doctor 2005, pp. 31-51).

$4 \quad$ Nges don 'brug sgra. This is its abbreviated title as referred to in the living tradition. The title appears variously as Gsang sngags snga 'gyur la bod du rtsod pa snga phyir byung ba rnams kyi lan du brjod pa nges don 'brug sgra, in (Sog bzlog pa Blo gros rgyal mtshan 1975b); or simply as Dris lan nges don 'brug sgra, in (Sog bzlog pa Blo gros rgyal mtshan 1982). There are multiple versions of the Thunder and its addendum available today, the details of which will be presented below. For the present article, I consulted (Sokdokpa 1975, 1982, 1985, 1999). For more on the life and writings of Sokdokpa, see (Gentry 2017).

5 Sokdokpa reproduces Lha Lama Yeshé Ö's edict in (Sog bzlog pa Blo gros rgyal mtshan 1975b, pp. 436.1-462.2, 1982, pp. 178.3-201.3, and 1999, pp. 467.3-504.3). He reproduces Potrang Shiwa Ö's edict in (Sog bzlog pa Blo gros rgyal mtshan 1975b, pp. 462.3-475.4, 1982, pp. 201.3-214.5, and 1999, pp. 504.3-522.4). These are the edicts, or "ordinances," reproduced, edited, and studied by (Karmay 1980a, 1980b), based on Sokdokpa's reproductions.

6 Sokdokpa reproduces this in (Sog bzlog pa Blo gros rgyal mtshan 1975b, pp. 475.4-488.1, 1982, pp. 214.5-228.1, 1999, pp. 522.4-538.5). It also circulates separately in ('Gos khug pa lhas btsas 1979, pp. 18-25). This 1979 version reflects copious substantial variations from how Sokdokpa produces it in the Thunder, despite Wangchuk's (2002, p. 276) claim that they are "the same." For an analysis of this text, see (Wangchuk 2002, pp. 275-77 and Wedemeyer 2014).

7 Sdom gsum rab dbye. Sokdokpa reproduces verses from this treatise in (Sog bzlog pa Blo gros rgyal mtshan 1975b, pp. 493.3-500.3, 1982, pp. 233.5-241.3, and 1999, pp. 547.6-557.6). See (Sakya Pandita Kunga Gyaltshen 2002) for an edition and translation. The verses Sokdokpa cites, either partially or in full, are as follows: III 167, 253-256, 260, 275-276, 280-283, 381, 507-509, 540, 604-610; cf. (Makidono 2011, pp. 234-35), who previously identified these, but appears to have mistakenly included verse 277 and recorded the typo of verse 405 for 605.

8 (Sog bzlog pa Blo gros rgyal mtshan 1975b, pp. 500.3-509.1, 1982, pp. 241.3-250.3, 1999, pp. 557.6-570.4) cites Bcom ldan rig pa'i ral gri (2006b), Bslab pa gsum rgyan gyi me tog, pp. 301.1, 334.2-336.4, 341.6, 342.1, 342.1-342.3, 389.4-389.5, 390.3-391.1, 391.2-391.5, 392.6-393.1; Sog bzlog pa Blo gros rgyal mtshan (1975b, pp. 500.3-509.1, 1982, pp. 241.3-250.3, 1999, pp. 557.6-570.4) cites Bcom ldan rig pa'i ral gri, Bstan pa rgyas pa rgyan gyi nyi 'od (in Schaeffer and van der Kuijp 2009, pp. 258-61); and Sog bzlog pa Blo gros rgyal mtshan (1975b, pp. 570.4-571.1) cites Bcom ldan rig pa'i ral gri (2006a), Gsang snying sgrub pa rgyan gyi me tog, pp. 143.2-144.6; the latter is cited in Sokdokpa's citation of Gyangro Jangchup Bum. Cf. (van der Kuijp 2016, p. 270fn163), who remarks that Sog bzlog pa records statements of this figure in (1975b pp. 570-572, 576, 583), which corresponds to (Schaeffer and van der Kuijp 2009, pp. 255-62). 
The section featuring these passages is (Sog bzlog pa Blo gros rgyal mtshan 1975b, pp. 544.2-601, 1982, pp. 289-346, and 1975b, pp. 620.5-699). It is unclear where these passages are drawn from. Gyangro Byangchup Bum also cites copiously from the works of his teacher Chomden Rigpé Reltri in these passages; cf. (van der Kuijp 2016, pp. 269-70, and p. 270fn163).

Sokdokpa devotes a separate section to Butön's History of Buddhism, but also cites him repeatedly throughout the Thunder. The separate Butön section appears in (Sog bzlog pa Blo gros rgyal mtshan 1975b, pp. 489.5-493.3, 1982, pp. 229.5-233.5, and 1999, pp. 542.5-547.5). The main section cited here corresponds to (Bu ston rin chen grub 1988, p. 266).

Chos dang chos ma yin rnam par dbye ba'i rab tu byed pa. Peldzin's text is reproduced fully in ((Sog bzlog pa Blo gros rgyal mtshan 1975b, pp. 262.1-435.6 (86.5 ff.)), 1982, pp. 1-178.3 (87/88 ff.), and 1999, pp. 225-467.3 (121 ff.)). It also circulated separately. To peruse this version, see www.tbrc.org (accessed on 13 October 2021), W1CZ885. Comparison reveals this manuscript to be nearly identical to what we find reproduced in Sokdokpa's text, aside from anonymous interlinear notes adorning its first five folios and its final folio. For more on the identity of the Old School critic Peldzin and his milieu see my forthcoming article.

This appears in (Sog bzlog pa Blo gros rgyal mtshan 1975b, pp. 509.1-544.2, 1982, pp. 250.3-285.4, and 1999, pp. 570.4-620.5). The corresponding passages appear in (Śākya mchog ldan 2006, vol. 17, pp. 515-599; Śākya mchog ldan 2013, vol. 17, pp. 387-408).

For details on the formation of Buddhist canons in Tibet, see (Harrison 1996; Skilling 1997; Schaeffer and van der Kuijp 2009; Almogi 2020).

Examples include (Achard 2015; Almogi 2020; Bajetta 2019; Davidson 2003, 2005; Higgins 2013; Kapstein 2000; Karmay 1975, 1980a, 1980b, 1988; van der Kuijp 2004, 2016; Makidono 2011; Martin 1994; Raudsepp 2009; Schaeffer and van der Kuijp 2009; Wangchuk 2002; Wedemeyer 2014). This is by no means an exhaustive list.

(Smith 1969). This preface, which introduces mKhan po Ngag dga's autobiography, 'Od gsal rin chen snying po padma la 'brel rtsal gyi rtogs brjod ngo mtshar sgyu ma'i rol gar, was subsequently reedited and presented in Among Tibetan Texts (Smith 2001, pp. 1-13) as "The Autobiography of the Rnying ma pa Visionary mKhan po Ngag dbang dpal bzang." (Smith 1969, p. 5 and fn13).

(Sog bzlog pa Blo gros rgyal mtshan 1975a).

Gsang sngags snga 'gyur la bod du rtsod pa snga phyir byung ba rnams kyi lan du brjod pa nges don 'brug sgra. (Sog bzlog pa Blo gros rgyal mtshan 1975b).

(Sog bzlog pa Blo gros rgyal mtshan 1999, 2009).

(Sog bzlog pa Blo gros rgyal mtshan 1997/1998).

(Smith 2004, p. 190; Gentry 2017, pp. 384-408; (Ngag dbang blo bzang rgya mtsho n.d., pp. $78-93$ (Sikkim version, pp. 80-95))). Sog bzlog bgyis tshul gyi lo rgyus, in (Sog bzlog pa Blo gros rgyal mtshan 1975a, vol. I, pp. 203-259). For details about this campaign in the context of a more extensive biographical portrait of Sokdokpa, see (Gentry 2017, pp. 90-133).

(Sog bzlog pa Blo gros rgyal mtshan 1975a, vol. I, 254.3-254.5).

(Mullard 2011, pp. 111, 112, 137).

For details on Sokdokpa's legacy in Sikkim via these figures, see (Gentry 2017, pp. 415-28).

(Tshering 2002, pp. 59-60).

For a bibliography of Sokdokpa's extant writings, including the texts in the Namchi Collected Writings and the published Assorted Writings, see (Gentry 2017, pp. 443-63).

(Sog bzlog pa Blo gros rgyal mtshan 1985).

(Sog bzlog pa Blo gros rgyal mtshan 1985, pp. 187-243).

(Rtse le Sna tshogs rang grol 1979, pp. 78.4, 81.6).

To peruse its catalogue of Tibetan texts, see https:/ / catalogue.ngmcp.uni-hamburg.de/content/search/tbtdocument.xed (accessed on 13 October 2021).

For a discussion of the Fifth Dalai Lama's references to Sokdokpa, see (Gentry 2017, pp. 384-408). For a brief discussion of Sangyé Gyatso's reference to Sokdokpa in his medical text Mirror of Beryl, see (Gentry 2019, p. 12).

(Gentry 2017, pp. 412-15).

For instance, the Thunder is referenced or directly cited by (Zhabs dkar tshogs drug rang grol (2002); (Rdzogs chen mkhan rabs XIII Padma badzra 2001, (1807/1808-1884) p. 149)), and (('Jam dbyangs mkhyen brtse'i dbang po 2009, (1820-1892), p. 31)).

(Sog bzlog pa Blo gros rgyal mtshan 1975a, vol. I, pp. 251.1-251.4; cf. (Gentry 2017, pp. 125-26).

(Sog bzlog pa Blo gros rgyal mtshan 1975b, p. 544.1, 1982, p. 285.3, 1999, p. 620.3): khro mo zhes pa shing pho[D mo, DA -] 'brug[D sbrul] gyi lo gro bzhin[emend. zhun] gyi[K-] zla ba'i tshes gcig. Cf. (Smith 1969, p. 5fn13; Schaeffer and van der Kuijp 2009, p. 49fn99). This calculation is based on (Schuh 1973, 2. Teil: Tabellen, p. 147).

Snyoms las can sog bzlog pa. 
(Sog bzlog pa Blo gros rgyal mtshan 1975b, pp. 601.1-601.2, 1982, pp. 341.6-342.1, 1985, p. 242.7, 1999, p. 699.2-699.3): sna tshogs dbyig ces pa shing mo sbrul gyi lo snron[D, K snon] gyis[D, DA gyi] nya ba'i dga' ba dang po'i tshes. This calculation is based on (Schuh 1973, 2. Teil: Tabellen, p. 147).

(Sog bzlog pa Blo gros rgyal mtshan 1975b, 1982, 1999): snyoms las pa; (Sog bzlog pa Blo gros rgyal mtshan 1985): sog bzlog pa'i ming can.

(Sog bzlog pa Blo gros rgyal mtshan 1975b, pp. 543.5-544.1, 1982, pp. 285.1-285.2, 1999, pp. 620.1-620.3).

(Sog bzlog pa Blo gros rgyal mtshan 1975b, p. 601.2, 1982, p. 342.1, 1999, p. 699.3-699.4).

(Sog bzlog pa Blo gros rgyal mtshan 1985, pp. 242.7-243.2).

(Dpa' bo gtsug lag phreng ba 1986, vol. 1, p. 713).

(Sog bzlog pa Blo gros rgyal mtshan 1976-1980, p. 532.2): chu mo yos kyi lo khrums zla ba'i tshe bcu.

(Sog bzlog pa Blo gros rgyal mtshan 1975a, vol. I, pp. 1-7). For a presentation of this catalogue, along with a bibliography of Sokdokpa's extant writings, see (Gentry 2017, pp. 443-463). The author of the tho byang uses first-person pronouns (rang nyid, bdag) not only in the opening lines (2.1) to describe his motives for composing the catalogue, but also, more tellingly, when giving the title of his memoir (2.3), "how I myself (rang nyid) repelled the Mongols, so as to benefit those who will repel the Mongols in future."

Sngags snying ma'i rtsod spong 'bri khung dpal 'dzin gyi brtsod lan.

Lha bla ma ye shes 'od kyi bka' shog gi lan du gsol ba le tshan gnyis.

Pho brang zhi ba 'od kyi bka' shog lan.

Lo tsā ba chen po mgos thas btsas kyi bka' shog gi lan.

Bcom ldan rig ral la lan du gsol ba'i yi ge.

Bdag nyid chen po sa kya pandita dang pan chen thams cad mkhyen pa bu ston chen po'i bzhed pa ji bzhin par bkral ba'i yi ge.

Bya pa chos rje bskal bzang pas pan chen mkhas pa'i dbang po śākya mchog ldan la dri ba'i lan du gnang ba sngags rnying ma'i rgyab brten bzang por gyur pa'i bskor nas btus pa.

Rang gi blo gzur bor bzhag pa'i yi ge rgyang rong byang chub 'bum gyi gsung rgyun thor bu'i rgyab skyor.

(Sog bzlog pa Blo gros rgyal mtshan 1975a, vol. I, pp. 2.3-3.2): ( . . dang bcas pa'di rnams dpe tshan phyogs gcig tu byas pa ... )

(Sog bzlog pa Blo gros rgyal mtshan 1975a, vol. I, p. 3.3).

The title page reads Thunder of Definitive Meaning: Expressed in Reply to Objections that Came Earlier and Later to the Early Translation School of Secret Mantra (Gsang sngags snga 'gyur la rtsod pa snga phyir byung ba rnams kyi lan du brjod pa nges pa don gyi 'brug sgra).

(Sog bzlog pa Blo gros rgyal mtshan 1975b, p. 543.5, 1982, pp. 284.6-285.1, 1999, pp. 619.6-620.1): Dam pa'i chos gsang sngags snga 'gyur la rtsod[DA brtsod] pa spong ba legs bshad nges pa don kyi 'brug sgra.

(Sog bzlog pa Blo gros rgyal mtshan 1975b, p. 601.1, 1982, p. 341.6, 1999, p. 699.2): Chos kyi rjes su 'brang ba dag la gtam du bya ba legs bshad bdud rtsi'i dga' ston; Sog bzlog pa Blo gros rgyal mtshan 1985, 242.6-.7: Rang gi the tshom sel[emend. gsel] ba'i gtam du bya ba legs bshad bdud rtsi'i dga' ston.

(Sog bzlog pa Blo gros rgyal mtshan 1975b (D), pp. 262.1-435.6, 1982 (DA), pp. 1-178.3, 1999 (K), pp. 225-467.3).

(Sog bzlog pa Blo gros rgyal mtshan 1975b (D), pp. 435.6-488.1, 1982 (DA), pp. 178.3-228.1, 1999 (K), pp. 467.3-538.5).

(Sog bzlog pa Blo gros rgyal mtshan 1975b (D), pp. 488.1-489.4, 1982 (DA), pp. 228.1-229.5, 1999 (K), pp. 538.5-542.5).

(Sog bzlog pa Blo gros rgyal mtshan 1975b (D), pp. 489.5-493.3, 1982 (DA), pp. 229.5-233.5, 1999 (K), pp. 542.5-547.5).

(Sog bzlog pa Blo gros rgyal mtshan 1975b (D), pp. 493.3-500.3, 1982 (DA), pp. 233.5-241.3, 1999 (K), pp. 547.6-557.6).

(Sog bzlog pa Blo gros rgyal mtshan 1975b (D), pp. 500.3-509.1, 1982 (DA), pp. 241.3-250.3, 1999 (K), pp. 557.6-570.4).

(Sog bzlog pa Blo gros rgyal mtshan 1975b (D), pp. 509.1-544.2, 1982 (DA), pp. 250.3-285.4, 1999 (K), pp. 570.4-620.5).

(Sog bzlog pa Blo gros rgyal mtshan 1975b (D), pp. 544.2-601, 1982 (DA), pp. 285.4-342, 1999 (K), pp. 620.5-699.4).

(Sog bzlog pa Blo gros rgyal mtshan 1975b (D), pp. 262.1-435.6, 1982 (DA), pp. 1-178.3, 1999 (K), pp. 225-467.3).

(Sog bzlog pa Blo gros rgyal mtshan 1975b (D), pp. 435.6-488.1, 1982 (DA), pp. 178.3-228.1, 1999 (K), pp. 467.3-538.5).

(Sog bzlog pa Blo gros rgyal mtshan 1975b (D), pp. 488.1-489.4, 1982 (DA), pp. 228.1-229.5, 1999 (K), pp. 538.5-542.5).

(Sog bzlog pa Blo gros rgyal mtshan 1975b (D), pp. 489.5-493.3, 1982 (DA), pp. 229.5-233.5, 1999 (K), pp. 542.5-547.5).

(Sog bzlog pa Blo gros rgyal mtshan 1975b (D), pp. 493.3-500.3, 1982 (DA), pp. 233.5-241.3, 1999 (K), pp. 547.6-557.6).

(Sog bzlog pa Blo gros rgyal mtshan 1975b (D), pp. 500.3-509.1, 1982 (DA), pp. 241.3-250.3, 1999 (K), pp. 557.6-570.4).

(Sog bzlog pa Blo gros rgyal mtshan 1975b (D), pp. 509.1-544.2, 1982 (DA), pp. 250.3-285.4, 1999 (K), pp. 570.4-620.5).

(Sog bzlog pa Blo gros rgyal mtshan 1975b (D), pp. 544.2-601, 1982 (DA), pp. 285.4-342, 1999 (K), pp. 620.5-699.4).

(Sog bzlog pa Blo gros rgyal mtshan 1975b (D), pp. 433.6-434.3, 1982 (DA), pp. 176.3-176.6, 1999 (K) pp. 464.3-465.2).

(Sog bzlog pa Blo gros rgyal mtshan 1975b (D), pp. 544.3-545.1, 1982 (DA), pp. 285.5-286.3, 1999 (K), pp. 620.6-621.5.)

(Sog bzlog pa Blo gros rgyal mtshan 1985 (N), pp. 188.3-189.6). 
(Sog bzlog pa Blo gros rgyal mtshan 1975b (D), p. 599.2-599.3, 1982 (DA), p. 340.3-340.4, 1999 (K), p. 697.3-.4; 1985 (N), p. 241.6). For more on this figure and his milieu, see my forthcoming article.

An initial consideration of this issue will be discussed in my forthcoming paper.

(Sog bzlog pa Blo gros rgyal mtshan 1975b (D), p. 596.3-596.4, 1982 (DA), pp. 337.6-338.1, 1999 (K), p. 694.1-694.3.

(Sog bzlog pa Blo gros rgyal mtshan 1985 (N), p. 239.3-239.6).

76 These two works of Lochen Rinchen Sangpo, long thought lost, have recently resurfaced and are currently available in (Rin chen bzang po 2018, pp. 139-210 and 30-138, respectively). For analysis of these two works, including a synoptic outline and list of text titles mentioned in the General Presentation of the Tantra Classes, see (van der Kuijp 2018b).

77 After this verse there is an interlinear note, mostly in verse, concerning controversies over the authenticity of the Six Dharmas of Nīgu and Nāro. Versions D and DA share this passage; version $\mathrm{K}$ is missing the final part of this passage; and $\mathrm{N}$ is missing it altogether.

78 The variations in this line can likely be chalked up to a misreading of the abbreviation (skung yig) for thams cad as 'thad and the addition of $n a$ at the end of the line to fill the shortened verse meter.

79 This text (Sog bzlog pa Blo gros rgyal mtshan 1975a, vol. II, pp. 1-143) refers to Sokdokpa's 1576 apologia composed in response to a polemical treatise directed against the Old School which was attributed to the Karmapa VIII Mikyö Dorje (Mi bskyod rdo rje, 1507-1554). Sokdokpa calculates his age here based on the Tibetan custom of counting from the year of conception, one year prior to his birth in 1552, making him "25 years old" in 1576, rather than 24 years old. For a discussion of Sokdokpa's text, Mikyö Dorje's writing that prompted it, and replies other than Sokdokpa's, see (Gentry 2017, pp. 171-290); and (van der Kuijp 2018b). This composition appears to have inaugurated Sokdokpa's career in Old School apologetics.

80 (Sog bzlog pa Blo gros rgyal mtshan 1975b (D), pp. 596.3-600.3; Sog bzlog pa Blo gros rgyal mtshan 1982 (DA), pp. 338.1-341.3; Sog bzlog pa Blo gros rgyal mtshan 1999 (K), pp. 694.3-698.4; Sog bzlog pa Blo gros rgyal mtshan 1985 (N),pp. 239.6-242.4).

(Sog bzlog pa Blo gros rgyal mtshan 1999, pp. 700.6-701/702).

\section{References}

'Gos khug pa lhas btsas. 1979. Sngags log sun 'byin. In Sngags log sun 'byin gyi skor. ff. 18.2-25.5. Thimpu: Kunsang Tobgyel and Mani Dorji. 'Jam dbyangs mkhyen brtse'i dbang po. 2009. Gangs can bod yul du byon pa'i gsang sngags gsar rnying gi gdan rabs mdor bsdus ngo mtshar padmo'i dga' tshal. In Sa skya'i chos 'byung gces bsdus. Beijing: Krung go'i bod rig pa dpe skrun khang, vol. 6, pp. 1-153.

Achard, Jean-Luc. 2015. The View of sPyi-ti Yoga. Revue d'Etudes Tibetaine 31: 1-20.

Almogi, Orna. 2019. The Human behind the Divine: An Investigation into the Evolution of Scriptures with Special Reference to the Ancient Tantras of Tibetan Buddhism. In Unearthing Himalayan Treasures: Festschrift for Franz-Karl Ehrhard. Indica et Tibetica 59. Edited by Volker Caumanns, Marta Sernesi and Nikolai Solmsdorf. Marburg: Indica et Tibetica Verlag, pp. 1-26.

Almogi, Orna. 2020. Authenticity and Authentication: Glimpses behind the Scenes of the Formation of the Tibetan Buddhist Canon. Indian and Tibetan Studies 9. Hamburg: Department of Indian and Tibetan Studies, Universistät Hamburg.

Bajetta, Nicolas. 2019. The Clear Realisation of the Quintessential Instructions on All Dharma Practices: A Critical Edition and Annotated Translation of the *Sarvadharmacaryopadeśäbhisamayatantra (Chos spyod thams cad kyi man ngag mngon par rtogs pa'i rgyud). Indian and Tibetan Studies 6. Hamburg: Department of Indian and Tibetan Studies, Universität Hamburg.

Bcom ldan rig pa'i ral gri. 2006a. Gsang snying sgrub pa rgyan gyi me tog. In Bcom ldan rig pa'i ral gri'i gsung 'bum. Lhasa: Khams sprul bsod nams don grub, vol. 10, pp. 142-79.

Bcom ldan rig pa'i ral gri. 2006b. Bslab pa gsum rgyan gyi me tog. In Bcom ldan rig pa'i ral gri'i gsung 'bum. Lhasa: Khams sprul bsod nams don grub, vol. 10, pp. 258-439.

Bdud 'joms 'Jigs bral ye shes rdo rje. 1967. Gangs ljongs rgyal bstan yongs rdzogs kyi phyi mo snga 'gyur rdo rje theg pa'i bstan pa rin po che ji ltar byung ba'i tshul dag cing gsal bar brjod pa lha dbang g.yul las rgyal ba'i rnga bo che'i sgra dbyangs. Kalimpong: Dudjom Tulku Rinpoche.

Bu ston rin chen grub. 1988. Bu ston chos 'byung (Bde bar gshegs pa'i bstan pa'i gsal byed chos kyi 'byung gnas gsung rab rin po che'i mdzod). Beijing: Krung go'i bod kyi shes rig dpe skrun khang.

Davidson, Ronald. 2003. gSar ma pa Apocrypha: The Creation of Orthodoxy, Gray Texts, and the New Revelation. In The Many Canons of Tibetan Buddhism. Edited by Helmut Eimer and David Germano. Leiden: Brill.

Davidson, Ronald. 2005. Tibetan Renaissance: Tantric Buddhism in the Rebirth of Tibetan Culture. New York: Columbia University Press.

Doctor, Andreas. 2005. Tibetan Treasure Literature: Revelation, Tradition, and Accomplishment in Visionary Buddhism. Ithaca: Snow Lion Publications.

Dpa' bo gtsug lag phreng ba. 1986. Chos 'byung mkhas pa'i dga' ston. 2 vols. Beijing: Mi rigs dpe skrun khang.

Dpal 'dzin. n.d. Chos dang chos ma yin pa rnam par dbye ba'i rab tu byed pa, 38 ff. TBRC: W1CZ885.

Dudjom, Rinpoche Jikdrel Yeshe Dorje. 1991. The Nyingma School of Tibetan Buddhism: Its Fundamentals and History. Translated by Gyurme Dorje, and Matthew Kapstein. Boston: Wisdom Publications.

Gentry, James Duncan. 2017. Power Objects in Tibetan Buddhism: The Life, Writings, and Legacy of Sokdokpa Lodrö Gyeltsen. Brill's Tibetan Studies Library 40. Leiden and Boston: Brill. 
Gentry, James Duncan. 2019. Arguing over the Buddhist Pedigree of Tibetan Medicine: A Case Study of EmpiricalObservation and Traditional Learning in 16th- and 17th-Century Tibet. Religions 10: 530. [CrossRef]

Harrison, Paul. 1996. A Brief History of the Tibetan bKa' 'gyur. In Tibetan Literature: Studies in Genre. Edited by José Cabézon and Roger Jackson. Ithaca: Snow Lion, pp. 70-94.

Higgins, David. 2013. The Philosophical Foundations of Classical rDzogs chen in Tibet: Investigating the Distinction between Dualistic Mind (sems) and Primordial knowing (ye shes). Vienna: Arbeitskreis für Tibetische und Buddhistische Studien Universität Wien.

Kapstein, Matthew. 2000. The Tibetan Assimilation of Buddhism: Conversion, Contestation, and Memory. Oxford and New York: Oxford University Press.

Karmay, Samten. 1975. The Doctrinal Position of rDzogs chen from the Tenth to the Thirteenth Centuries. Journal Asiatique, Tome CCLXIII 1-2: 147-56.

Karmay, Samten. 1980a. The Ordinance of 1Ha Bla-ma Ye-shes-'od. In Tibetan Studies in Honour of Hugh Richardson. Edited by Michael Aris and Aung San Suu Kyi. Warminster: Aris and Phillips, pp. 150-60.

Karmay, Samten. 1980b. An Open Letter by Pho-brang Zh-ba-'od. The Tibet Journal V-3: 1-28.

Karmay, Samten. 1988. The Great Perfection: A Philosophical and Meditative Teaching of Tibetan Buddhism. Leiden: Brill.

Lopez, Donald. 1996. Polemical literature (dGag lan). In Tibetan Literature: Studies in Genre. Edited by José Cabézon and Roger Jackson. Ithaca: Snow Lion, pp. 217-29.

Makidono, Tomoko. 2011. An Entrance to the Practice Lineage as exemplified in Kah thog Dge rtse Mahāpaṇitita's Commentary on Sa skya Pandita's Sdom gsum rab dbye. Revue d'Etudes Tibétaines 22: 215-42.

Martin, Dan. 1994. Unearthing Bon Treasures: Life and Contested Legacy of a Tibetan Scripture Revealer, with a General Bibliography of Bon. Leiden: Brill.

Mayer, Robert. 1997. Were The gSar ma pa Polemicists Justified in Rejecting Some rNying ma pa Tantras? In Proceedings of the 7th Seminar of the International Association for Tibetan Studies. Edited by Ernst Steinkellner. Vienna: Verlag der Österreichischen Akademie der Wissenschaften, vol. II.

Mullard, Saul. 2011. Opening the Hidden Land: State Formation and the Construction of Sikkimese History. Leiden: Brill.

Ngag dbang blo bzang rgya mtsho. n.d. Bca' yig drang srong ri shi'i dkyil 'khor, 'Phags bal bod dang bod chen rgya hor sog pos mtshon mchog dman bar ma mtha' dag gi spyi bye brag legs nyes 'byed pa'i bca' yig lam yig bsko 'ja' sogs bkod pa khrims gnyis gser shing phun tshogs 'dod 'jo. In Ngag dbang blo bzang rgya mtsho gsung 'bum. Beijing: Yellow Pagoda, vol. 20 (Wa), pp. 78-93.

Onians, Isabelle. 2003. Tantric Buddhist Apologetics or Antinomianism as a Norm. Ph.D. dissertation, Oxford University, Oxford, UK.

Raudsepp, Kadri. 2009. Dating and Authorship Problems in the Sngags log sun 'byin Attributed to Chag lo tsā ba Chos rje dpal. In Contemporary Visions in Tibetan Studies. Edited by Brandon Dotson, Kalsang Norbu Gurung, Georgios Halkias and Tim Myatt. Chicago: Serindia Publications, pp. 281-97.

Rdzogs chen mkhan rabs XIII Padma badzra. 2001. Snga 'gyur rnying ma'i gzhung la brgal ba'i lan lung dang rigs pa'i skya rengs. In Padma badzra gsung thor bu. Chengdu: Si khron mi rigs dpe skrun khang, pp. 133-42.

Rin chen bzang po. 2018. Rin chen bzang po gsung 'bum. Lhasa: Bod ljongs bod yig dpe rnying dpe skrun khang.

Rtse le Sna tshogs rang grol. 1979. Snyigs dus kyi bla ma'i gzugs bsnyan 'dzin pas rang gi mtshan nyid ji lta bar brjod pa drang po'i sa bon. In The Complete Works of Rtse-le Rgod-tshang-pa Padma-legs-grub. Gangtok: Mgon-po-tshe-brtan, Palace Monastery, vol. 1, pp. 1-200.

Sākya mchog ldan. 2006. Mkha' spyod dbang po'i spyan drung du 'bul ba'i mol mchid sogs. In Śākya mchog ldan gsung 'bum. Kathmandu: Sachen International, Guru Lama, vol. 17, pp. 515-99.

Sākya mchog ldan. 2013. Gser gyi thur ma las brtsams pa'i dogs gcod kyi 'bel gtam rab gsal rnam nges sam nges don rab gsal. In Gser mdog paṇ chen Śäkya mchog ldan gyi gsung 'bum. Beijing: Krung go'i bod rig pa dpe skrun khang, vol. 17, pp. 387-408.

Sakya Pandita Kunga Gyaltshen. 2002. A Clear Differentiation of the Three Codes. Translated by Jared Douglas Rhoton. Albany: SUNY.

Schaeffer, Kurtis R., and Leonard W. J. van der Kuijp. 2009. An Early Tibetan Survey of Buddhist Literature: The Bstan pa rgyas pa rgyan gyi nyi 'od of Bcom ldan ral gri. The Harvard Oriental Series; Cambridge and London: The Department of Sanskrit and Indian Studies, Harvard University.

Schuh, Dieter. 1973. Untersuchungen zur Geschichte der tibetischen Kalenderrechnung, Verzeichnis der Orientalischen Handschriften in Deutschland, Supplement Band 16. Wiesbaden: Franz Steiner Verlag.

Skilling, Peter. 1997. From bKa' bstan bcos to bKa' 'gyur and bsTan 'gyur. In Transmission of the Tibetan Canon. Papers Presented at a Panel of the 7th Seminar of the International Association for Tibetan Studies, Graz 1995. PIATS 3. Edited by Helmut Eimer. Beiträge zur Kultur-und Geistesgeschichte Asiens 22. Österreichische Akademie der Wissenschaften. Philosophisch-historische Klasse, Denkschriften 257. Vienna: Verlag der Österreichischen Akademie der Wissenschaften, pp. 87-111.

Smith, E. Gene. 1969. Preface. In The Autobiographical Reminiscences of Ngag-dbang-dpal-bzang, Late Abbot of Kah-thog Monastery. The Ngagyur Nyingma Sungrab Publication Series; New Delhi and Gangtok: Sonam T. Kazi, vol. 1.

Smith, E. Gene. 2001. Among Tibetan Texts: History and Literature of the Himalayan Plateau. Boston: Wisdom Publications.

Smith, E. Gene. 2004. Banned Books in the Tibetan-Speaking Lands. In 21st Century Tibet Issue: Symposium on Contemporary Tibetan Studies. Collected Papers. Taipei: Mongolian and Tibetan Affairs Commission, pp. 368-81.

Sog bzlog pa Blo gros rgyal mtshan. 1975a. Collected Writings of Sog-bzlog-pa Blo-gros-rgyal-Mtshan. 2 vols. New Delhi: Sanji Dorji.

Sog bzlog pa Blo gros rgyal mtshan. 1975b. Nges don 'brug sgra. In Collected writings of Collected Writings of Sog-bzlog-pa Blo-gros-rgyalmtshan. New Delhi: Sanji Dorji, vol. I, pp. 261-601. 
Sog bzlog pa Blo gros rgyal mtshan. 1976-1980. Jam dpal tshe bdag yang zlog me'i spu gri'i man ngag. In Rin chen gter mdzod chen mo. Paro: Ngodrup and Sherab Drimay, vol. 83 Phi ('i), pp. 515-32.

Sog bzlog pa Blo gros rgyal mtshan. 1982. Dris lan nges don 'brug sgra. Dalhousie: Damchoe Sangpo.

Sog bzlog pa Blo gros rgyal mtshan. 1985. Several hitherto undiscovered writings of the Rñin-ma-pa master, Sog-bzlog-pa Blo-gros-rgyal-mtshan (Sog bzlog pa Blo gros rgyal mtshan gsung thor bu). Gangtok: Dzongsar Khyentse Labrang, Palace Monastery.

Sog bzlog pa Blo gros rgyal mtshan. 1997/1998. Dris lan nges don 'brug sgra, 4-340. Chengdu: Sichuan Nationalities Publishing House.

Sog bzlog pa Blo gros rgyal mtshan. 1999. Nges don'brug sgra. In Bka' ma shin tu rgyas pa (Kah thog). 120 vols. Chengdu: Kah thog mkhan po 'jam dbyangs, vol. 116 (Le), pp. 225-702.

Sog bzlog pa Blo gros rgyal mtshan. 2009. Nges don 'brug sgra. In Bka' ma shin tu rgyas pa. 133 vols. Chengdu: Si khron dpe skrun tshogs pa, Si khron mi rigs dpe skrun khang, vol. 130 (Tho), pp. 1-430.

Tshering, Khenpo L. 2002. Mkha' spyod 'bras mo ljongs kyi gtsug nor sprul pa'i rnal 'byor mched bzhi brgyud 'dzin dang bcas pa'i byung ba brjod pa blo gsar gzhon nu'i dga' ston. Gangtok: Khenpo L. Tshering.

van der Kuijp, Leonard W. J. 2004. The Kālacakra and the Patronage of Tibetan Buddhism by the Mongol Imperial Family. Bloomington: Department of Central Eurasian Studies, Indiana University.

van der Kuijp, Leonard W. J. 2016. The Lives of Bu ston Rin chen grub and the Date and Sources of His Chos 'byung, a Chronicle of Buddhism in India and Tibet. Revue d'Etudes Tibétaine 35: 203-308.

van der Kuijp, Leonard W. J. 2018a. The Bird-faced Monk and the Beginnings of the New Tantric Tradition, Part One. In Tibetan Genealogies: Studies in Memoriam of Guge Tsering Gyalpo (1961-2015). Edited by Guntram Hazod and Shen Weirong. Beijing: China Tibetology Publishing House, pp. 403-50.

van der Kuijp, Leonard W. J. 2018b. The Bird-faced Monk and the Beginnings of the New Tantric Tradition, Part Two. Journal of Tibetology 19: 86-127.

Wangchuk, Dorji. 2002. An Eleventh-Century Defence of the Guhyagarbhatantra. In The Many Canons of Tibetan Buddhism. PIATS 2000: Proceedings of the Ninth Seminar of the International Association for Tibetan Studies. Edited by Helmut Eimer and David Germano. Leiden and Boston: Brill, pp. 265-91.

Wedemeyer, Christian. 2014. Sex, Death, and 'Reform' in Eleventh-century Tibetan Buddhist Esoterism: 'Gos Khug pa Lhas btsas, spyod pa (caryā), and mngon par spyod pa (abhicāra). In Sucāruvādadeśika. A Festschrift Honoring Professor Theodore Riccardi. Edited by Todd Lewis and Bruce McCoy Owens. Kathmandu: Himal Books, pp. 240-60.

Zhabs dkar tshogs drug rang grol. 2002. Legs bshad kun bzang mchod sprin. In Tshogs drug rang grol gsung 'bum. Xining: Mtsho sngon mi rigs dpe skrun khang, vol. 10, pp. 103-364. 